\title{
The Preparation of, and Studies on, Free Cell Suspensions from Mouse Pancreatic Islets
}

\author{
A. Lernmark \\ Department of Histology, University of Umeå, Umeå, Sweden \\ Received: February 5, 1974, and in revised form: May 27, 1974
}

\begin{abstract}
Summary. Pancreatic islets, isolated from the pancreas of obese-hyperglycemic mice, were used to prepare free islet cells in suspension. Batches of 100 islets were disrupted by mechanical shaking for 10 sec in a $\mathrm{Ca}^{2+}$-free HEPES-buffered Krebs-Ringer medium containing $1 \mathrm{mM}$ EGTA. From 200-500 islets, about $2.2 \times 10^{6}$ cells could be obtained in suspension, corresponding to a yield of roughly $55 \%$ as calculated from the content of DNA in cells and islets. The isolated islet cells appeared wellpreserved in the light and the electron microscope and
\end{abstract}

seemed to exhibit a high degree of viability as judged by viable cell counts, a radioactive assay for lysis and insulin release. Insulin release from islet cell suspensions, as calculated per cell, per content of DNA or insulin or per packed cell volume, was stimulated by glucose alone or in combination with theophyliine. The glucose response was low compared with that of intact isolated islets.

Key words: Isolated islet cells, ob/ob mouse islets, islet disruption, DNA content, insulin release.
Pancreatic islets isolated by freehand microdissection $[7,11]$ or by collagenase treatment of the pancreas $[22,15]$ are extensively used for studying the mechanisms of insulin and glucagon secretion, However, the isolated islet is a complex model, not only because it contains at least four types of endocrine cells [14, 10] but also because other structural elements are present, such as blood vessels, a surrounding connective tissue capsule and basement membranes. The latter structures constitute possible barriers which could well interfere with molecules' entering or leaving the incubated, isolated islet, especially as it has lost its capillary system. It was therefore considered of value to develop a procedure for the isolation of free islet cells, which could then be studied in suspension. The availability of a free islet cell suspension should make it possible to study the direct effects of any substance on the isolated cells and permit more detailed investigations of transport kinetics uncomplicated by consideration of diffusion in an extracellular space.

The present communication describes a non-enzymatic technique for dispersing the cellular elements of pancreatic islets isolated by collagenase treatment of the pancreas from obese-hyperglycemic mice. These animals were chosen since a considerable number of enlarged $\beta$-cell-rich islets could easily be isolated.

\section{Materials and Methods}

\section{Chemicals}

Crude collagenase $(142 \mathrm{U} / \mathrm{mg})$ was obtained from Worthington Biochemical Corp., Freehold, N.J. Sigma Chemical Co., St. Louis, Mo. supplied the hyaluronidase (Type III, $600 \mathrm{NF}$ Units/mg), pronase (protease, repurified type IV), bovine serum albumin, fraction $V$ (BSA), calf thymus DNA and theophylline. D-glucose,
1,2-di(2-aminoethoxy)ethane-N,N,N',N'-tetra acetic acid (EGTA) and N-2-hydroxyethylpiperazine-N'-2ethane sulphonic acid (HEPES) were from British Drug Houses Ltd., Poole, Dorset, U.K. AB Kabi, Stockholm, Sweden, supplied the human serum albumin, grade A (HSA), New England Nuclear, Boston, Mass., the ${ }^{51} \mathrm{Cr}$-sodium chromate and Aldrich Chemical Co., Milwaukee, Wis., the 3,5-diaminobenzoic acid dihydrochloride (DABA). ${ }^{125} \mathrm{I}$-insulin was from Farbwerke Hoechst AG, Frankfurt/Main, Germany, and insulin antibodies from Wellcome Reagents Ltd., Beckenham, Kent, U.K. Glucagon antiserum (batch K 52) and 125I-labelled glucagon were kindly donated by Dr. Lise G. Heding, Novo Research Institute, Copenhagen, Denmark. Crystalline mouse insulin and erystalline porcine glucagon were generously supplied by Novo Industry A/S, Copenhagen, Denmark. Commercially available reagents of analytical grade and distilled and deionized water were used throughout the investigation. All glass and plastic ware coming in contact with tissues or cells was siliconized with Siliclad ${ }^{\circledR}$ (Clay Adams, Parsippany, N.J.).

\section{Incubation Medium}

The medium employed was a Krebs-Ringer solution [30] buffered with HEPES ( $\mathrm{pH}$ 7.3). The basal medium, which will be referred to as KR-HEPES medium, contained $115 \mathrm{mM} \mathrm{NaCl}, 4.7 \mathrm{mM} \mathrm{KCl}, 2.56 \mathrm{mM}$ $\mathrm{CaCl}_{2}, 1.2 \mathrm{mM} \mathrm{KH}_{2} \mathrm{PO}_{4}, 1.2 \mathrm{mM} \mathrm{MgSO}{ }_{4} .7 \mathrm{H}_{2} \mathrm{O}, 20 \mathrm{mM}$ $\mathrm{NaHCO}_{3}$ and $16 \mathrm{mM}$ HEPES. All incubations were carried out at $37^{\circ} \mathrm{C}$ after equilibrating the medium with air.

\section{Animals and Isolation of Islets}

Adult, female obese-hyperglycemic mice (gene symbol $o b / o b$ ) from a local colony were starved overnight before being killed by decapitation. Islets were 
isolated by collagenase treatment of the pancreas [22, 15]. In each experiment, the pancreata from two animals were placed in KR-HEPES medium containing $1 \mathrm{mg} / \mathrm{ml}$ BSA and $5 \mathrm{mM}$ glucose. The pancreatic tissue was cut into small pieces (ca. $2 \times 2 \mathrm{~mm}$ ) which were incubated in ordinary glass scintillation vials in $2 \mathrm{ml}$ of the same medium supplemented with $3 \mathrm{mg}$ collagenase. After incubation for $20 \mathrm{~min}$ at $37^{\circ} \mathrm{C}$ with rapid shaking (240 strokes/min) the incubation mixture was transferred to a conical tube $(110 \times 15 \mathrm{~mm})$, resuspended to $10 \mathrm{ml}$ with collagenase-free medium and centrifuged (Wifug, Stockholm, Sweden) at room temperature for $3 \mathrm{~min}$ at 300 r.p.m. The supernatant was discarded and the sediment resuspended in fresh KRHEPES medium. This washing procedure was repeated five times; in the last two washings the islets were allowed to settle without centrifugation. The final sediment was transferred to a perspex cup. Under a stereomicroscope $200-500$ islets were collected with the aid of a braking pipette. These steps in the isolation procedure took roughly $30-40 \mathrm{~min}$.

\section{Isolation of Free Islet Cells}

The procedure for isolating free islet cells will be described in detail in the Results section.

\section{Counting of Cells}

Cell numbers were determined by simple counting in a haemocytometer. Samples of free islet cell suspensions were stained with a solution containing $0.1 \%$ $(w / v)$ methylene blue, $0.125 \%(w / v)$ glutaraldehyde and $1 \mathrm{mM}$ EGTA in $\mathrm{Ca}^{2+}$-free KR-HEPES medium. The cells were allowed to stand in this solution for 5 10 min at room temperature and the suspension was gently shaken before samples were transferred to the haemocytometer.

\section{Preparation of Free Islet Cells for Electron Microscopy}

Because of the small amounts of material available, the entire preparative procedure for electron microscopy was carried out in BEEM-capsules (LKB-Beckman Instrument AB, Stockholm, Sweden). The isolated cells in suspension were fixed by adding ice-cold glutaraldehyde in $0.1 \mathrm{M}$ phosphate buffer ( $\mathrm{pH} 7.3$ ) to the suspension medium. Fixation time was 2 hr at $4^{\circ} \mathrm{C}$. The cells were then centrifuged down and washed by resuspension in the phosphate buffer containing $0.2 \mathrm{M}$ sucrose. They were post-fixed in $1 \%$ phosphate-buffered osmium tetroxide ( $\mathrm{pH} 7.3$ ) for $1 \mathrm{hr}$ at $4^{\circ} \mathrm{C}$. After rinsing in distilled water, the cells were again centrifuged, the pellets were dehydrated in a graded series of ethanol, and via propylene oxide they were embedded in Epon 812 [19]. Sections were cut on an LKB ultratome, stained with lead citrate and uranyl acetate and examined in a Philips EM 300 electron microscope.

\section{Viability Tests}

To estimate cell viability, a cytotoxic assay was used as described by Wigzell [31]. This assay is based on ${ }^{51} \mathrm{Cr}$-labelling of intact cells and was carried out in KR-HEPES medium containing $10 \mathrm{mg} / \mathrm{ml} \mathrm{HSA}$ and 3 or $20 \mathrm{mM}$ glucose. Viable cell count was performed with $0.2 \%(\mathrm{w} / \mathrm{v})$ trypan blue alone [21] or with trypan blue and neutral red used in sequence as described by DeRenzis and Schechtman [2].

\section{Chemical Assays}

Insulin and glucagon were determined radioimmunologically. Free and antibody-bound hormone were separated by ethanol precipitation $[5,6]$. Mouse insulin and porcine glucagon were used as standards. DNA was determined by the Kissane-Robbins [12] fluorometric assay as modified by Clark [1]. All samples for assay of DNA were freeze-dried and sonicated (Branson Sonic Power Co., Danbury, Conn. Sonifier B-12 equipped with a microtip and run at a meter reading of $50 \mathrm{~W}$ for $15 \mathrm{sec}$ ) before extraction. Calf thymus DNA in a range of $0.05-1.6 \mu \mathrm{g} / 10 \mu \mathrm{l}$ water was used as standard.

\section{Results}

\section{Disruption of Pancreatic Islets}

A) Washed collagenase-isolated islets were transferred to fresh $\mathrm{Ca}^{2+}$-free $\mathrm{KR}$-HEPES medium containing $1 \mathrm{mM}$ EGTA, $3 \mathrm{mM}$ glucose and $10 \mathrm{mg} / \mathrm{ml} \mathrm{HSA}$. Batches of 100 islets per $200 \mu l$ medium in polypropylene micro test tubes (Milian Instruments SA, Geneva, Switzerland) were shaken for $10 \mathrm{sec}$ in a modified Beckman micromixer (Beckman Instruments SA, Geneva, Switzerland, Model 154). Shaking for 10 or 15 sec was sufficient to completely disrupt the islets (Fig. 1). It was obvious that the longer the shaking time, the smaller the number of intact cells recovered. Omission of both $\mathrm{Ca}^{2+}$ and $\mathrm{Mg}^{2+}$ from the medium did not increase the number of free cells that could be isolated from 100 islets (Fig. 1). High concentrations of serum albumin $(4-5 \%, w / v)$ or the absence of EGTA impeded islet disruption.

B) The dispersive effects of enzyme-treatment on isolated islets were also studied. Batches of $30-40$ islets were incubated for 30 to $60 \mathrm{~min}$ in the presence of either $1 \mathrm{mg} / \mathrm{ml}$ crude collagenase and $2 \mathrm{mg} / \mathrm{ml}$ hyaluronidase or $2.5 \mathrm{mg} / \mathrm{ml}$ pronase. In neither case did the enzyme treatment by itself cause islet disruption. However, free cells could easily be obtained by shaking after the enzyme treatment.

\section{Recovery of Free Cells}

The free cell suspensions obtained by method A) above were carefully transferred to plastic tubes $(9 \times$ $30 \mathrm{~mm}$ ) and diluted 1:4 with EGTA-free KR-HEPES medium containing $\mathrm{Ca}^{2+}$ and $10 \mathrm{mg} / \mathrm{ml}$ HSA. The suspension was washed three times at room temperature by repeated centrifugation for $1 \mathrm{~min}$ at $50 \times \mathrm{g}$, and the cells were carefully resuspended. An average number of free cells obtained after this procedure is given 
in Table 1. In each experiment 200-500 islets were isolated from the pancreata of two animals.

In a separate experiment, the mean islet dry weight in batches of $50-100$ islets was determined and found to be roughly $3 \mu \mathrm{g}$. The amount of DNA/ $\mu \mathrm{g}$ dry islet was estimated to $1.8 \%$ (Table 1 ). The DNA content per islet cell was found to be about $5 \mathrm{pg}$ (Fig. 2 and Table 1). From these figures it could be calculated that the approximative number of cells present in $200-$ 500 islets was $4.1 \times 10^{6}$. As shown in Table $1,2.2 \times$ $10^{6}$ cells could be recovered from each batch of islets. Thus the yield of isolated cells amounted to roughly $55 \%$ of the total number of cells present in the islets.

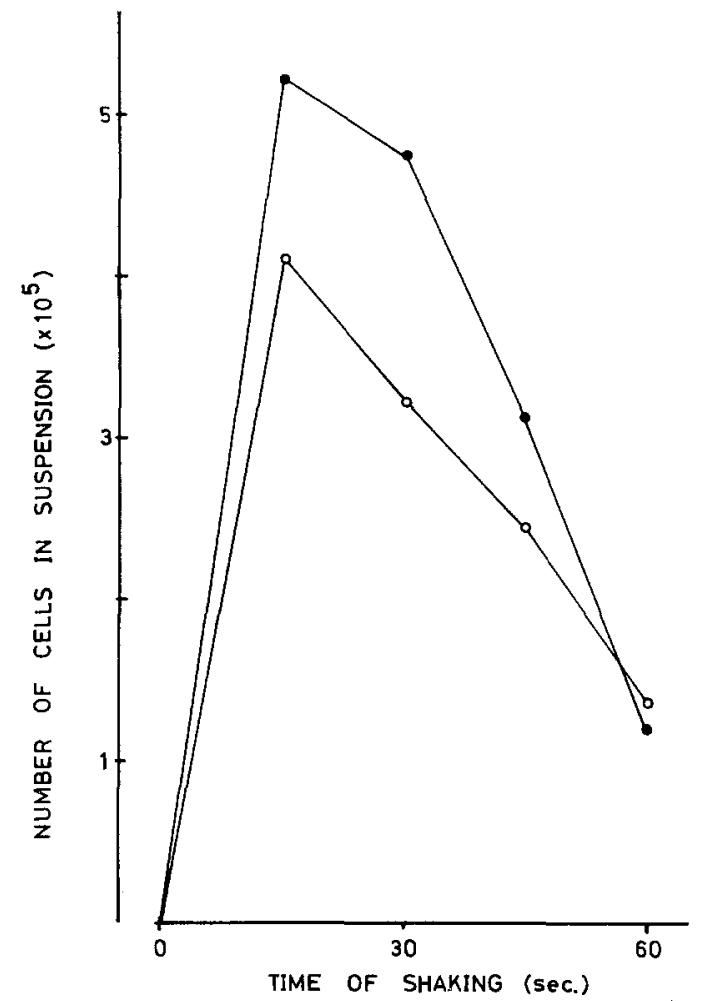

Fig. 1. Effect of time on the disruption of isolated islets by shaking. Batches of 100 islets per $200 \mu$ l Krebs-Ringer HEPES medium were shaken in polypropylene micro test tubes. At $15 \mathrm{sec}$ intervals the shaking was interrupted and a sample was removed for cell counting. The medium was supplemented with $1 \mathrm{mM}$ EGTA with either $\mathrm{Ca}^{2+}$

$(-)$ or both $\mathrm{Ca}^{2+}$ and $\mathrm{Mg}^{2+}(\mathrm{O}-\mathrm{O})$ omitted

\section{Cell Morphology}

Unstained free islet cells, examined in the haemocytometer, are shown in Fig. 3 . The cells showed some tendency to clump. Although the vast majority of the cells were round in outline and seemed to be intact, occasional isolated nuclei were observed, as were cells with slightly irregular or even torn contours. An isolated $\beta$-cell as visualized in the electron microscope is depicted in Fig. 4. The cell is well preserved and exhibits all the features of a normal $\beta$-cell as described in numerous electron microscopical investigations on
Table 1. Islets for DNA determinations were microdissected from the pancreas of obese-hyperglycemic mice. The islets were frozen in melting isopentane $\left(-160^{\circ} \mathrm{C}\right)$, freeze-dried overnight $\left(-40^{\circ} \mathrm{C}, 0.001 \mathrm{~mm} \mathrm{Hg}\right)$ and weighed on a quartz fiber balance. Batches of islet weighing $10-100 \mu g$ were extracted for $D N A$ analyses. The amounts of $D N A$ per cell were calculated from Fig. 2. To prepare free islet cells, 200500 islets were isolated in each experiment. In a separate experiment the mean islet dry weight in batches of $50-100$ islets was found to be roughly $3 \mathrm{\mu g}$. From this figure, the approximate total islet dry weight and the approximate total number of cells in the islet batches were calculated. The number of free islet cells was counted in samples taken from suspensions of cells immediately upon isolation.

\begin{tabular}{|c|c|c|}
\hline Parameter & $\begin{array}{l}\text { No. of } \\
\text { exp. }\end{array}$ & Mean value $\pm \mathrm{SEM}$ \\
\hline ng DNA/kg dry islet & 10 & $18.34 \pm 1.94$ \\
\hline pg DNA/cell & 37 & $5.12 \pm 0.24$ \\
\hline $\begin{array}{l}\text { No of islets used for } \\
\text { preparing free cells }\end{array}$ & 10 & $380 \pm 24$ \\
\hline $\begin{array}{l}\text { Approx. total islet dry } \\
\text { weight }(\mu g)\end{array}$ & 10 & $1140 \pm 74$ \\
\hline $\begin{array}{l}\text { Approx. total no. of cells } \\
\text { present in the isolated } \\
\text { islets }\left(\times 10^{6}\right)\end{array}$ & 10 & $4.10 \pm 0.27$ \\
\hline $\begin{array}{l}\text { No. of isolated free islet } \\
\text { cells }\left(\times 10^{6}\right)\end{array}$ & 10 & $2.23 \pm 0.33$ \\
\hline$\%$ cell yield & 10 & $55 \pm 8$ \\
\hline
\end{tabular}

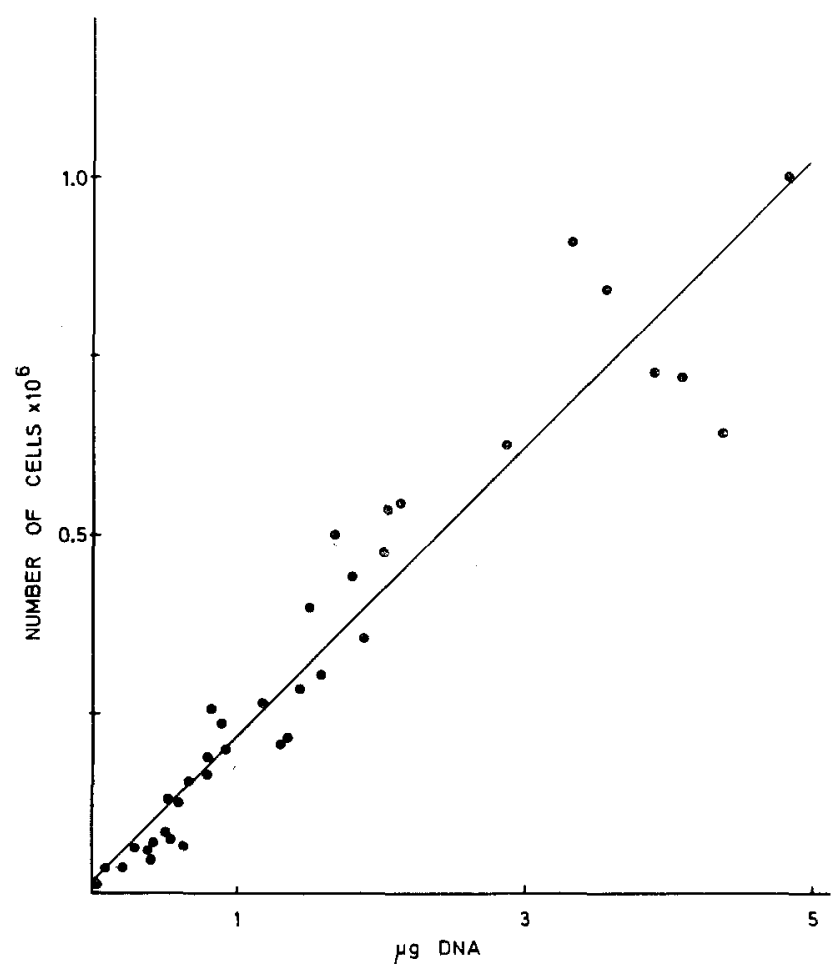

Fig. 2. Relationship between the number of free islet cells and content of DNA. Immediately upon isolation, duplicate samples of free islet cells in four different experiments were serially diluted in Krebs-Ringer HEPES medium containing $5 \mathrm{mM}$ glucose and $10 \mathrm{mg} / \mathrm{ml}$ HSA. Number of cells and content of DNA were determined in duplicate samples from each dilution. The regression line was $y=$ $0.201 \mathrm{x}+0.017$, the regression coefficient being $\mathbf{r}=$ $0.9539(n=37)$ 
mouse pancreatic islets. The granule population is dense and the individual granules show their characteristic dense core separated from the perigranular membrane by an electron-lucid space. The endoplasmic reticulum is well-developed and mitochondria of classical type are dispersed throughout the cytoplasm.

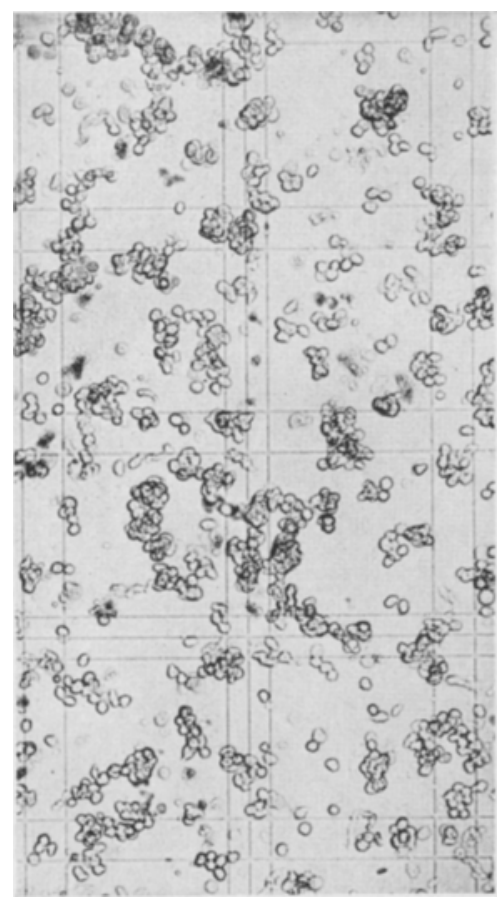

Fig. 3. Free islet cells suspended in Krebs-Ringer HEPES medium containing $3 \mathrm{mM}$ glucose and $10 \mathrm{mg} / \mathrm{ml} \mathrm{HSA}$ and examined in the haemocytometer. X330

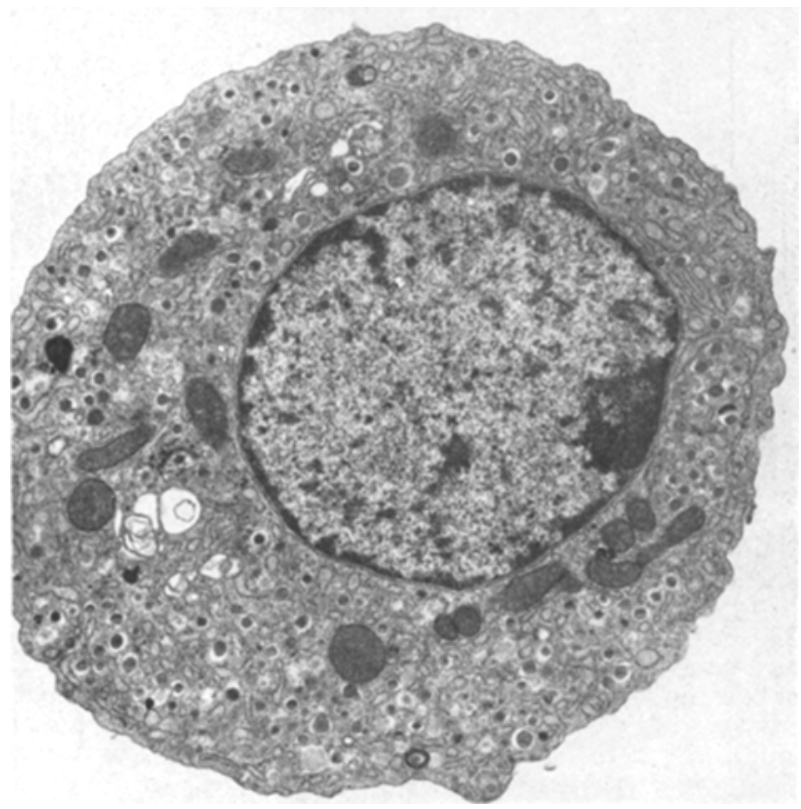

Fig. 4. Electron micrograph of an isolated pancreatic $\beta$-cell. X7500
Occasional $\beta$-cells showed certain degenerative features such as peripheral, cytoplasmic blebs, widened and distorted cisternae of the endoplasmic reticulum, disruption of perigranular membranes within certain cytoplasmic areas and a general decrease in electron density of the cytoplasmic ground substance.

In the electron microscopic study of large numbers of isolated islet cells connective tissue elements or exocrine cells were rarely encountered.

\section{Cell Viability}

The viability and/or stability of the isolated islet cells was studied in separate experiments. In islet cell samples immediately upon isolation, $17 \pm 3 \%$ (mean value \pm SEM for 5 experiments) of the cells took up trypan blue. The relative number of stained cells did not change significantly if the cells were incubated for $5-60 \mathrm{~min}$ in the presence of $3 \mathrm{mM}$ or $20 \mathrm{mM}$ glucose.

To establish whether loss of cells occurred, e.g. due to lysis, cell counts were performed before and after incubation for $120 \mathrm{~min}$. About $3.3 \pm 0.4 \times 10^{4}$ cells (mean value \pm SEM for six experiments) were first preincubated for $60 \mathrm{~min}$ in $5 \mathrm{ml} \mathrm{KR-HEPES} \mathrm{medium}$ containing $3 \mathrm{mM}$ glucose. After centrifugation $(5 \mathrm{~min}$ at $50 \times \mathrm{g}$ ) and removal of $4.8 \mathrm{ml}$ of the medium, the cells were resuspended and incubated for an additional $60 \mathrm{~min}$ in $2 \mathrm{ml}$ of fresh medium. After a final centrifugation, the number of cells recovered amounted to $3.4 \pm 0.5 \times 10^{4}$ (mean value $\pm \mathrm{SEM}$ for six experi-

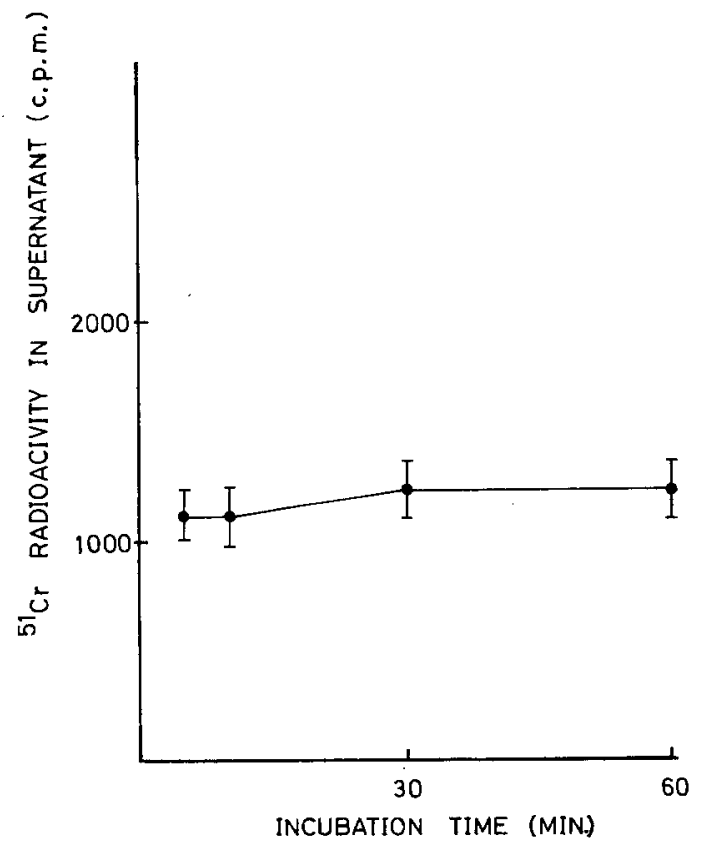

Fig. 5. Radioactivity of ${ }^{51} \mathrm{Cr}$ release from prelabelled free islet cells (about $10^{4}$ cells per tube) incubated in KrebsRinger HEPES medium containing $3 \mathrm{mM}$ glucose and $10 \mathrm{mg} / \mathrm{ml}$ HSA. The supernatant was obtained after centrifuging the cells at $300 \mathrm{xg}$ for $2 \mathrm{~min}$. Mean values \pm SEM for four different experiments 
ments). Further evidence that lysis did not occur was obtained by incubating ${ }^{51} \mathrm{Cr}$-labelled islet cells for 5 $60 \mathrm{~min}$. There was no significant increase of free radioactivity in the medium (Fig. 5). containing $3 \mathrm{mM}$ glucose. The suspensions were then centrifuged for 5 min at $50 \times \mathrm{g}$. The cell pellets were rapidly frozen and were freeze-dried before being assayed. The contents of insulin and glucagon amounted

Table 2. Effects of glucose and theophylline on insulin release from free islet cell suspensions. A) Insulin release per cell or ug DNA. Free islet cells (about $1.3 \times 10^{5}$ cells per tube) were first preincubated for 60 min in $5 \mathrm{ml} K R$-HEPES medium containing $3 \mathrm{mM}$ glucose and $10 \mathrm{mg} / \mathrm{ml}$ HSA. Following centrifugation at room temperature for 5 min at $50 \mathrm{xg}, 4.8 \mathrm{ml}$ medium was removed for insulin determination and the cell pellet was resuspended in $2 \mathrm{ml}$ medium supplemented as indicated in the table. The cells were incubated for 60 min, centrifuged again and the supernatant was removed for insulin assay. Number of cells and content of DNA were estimated in samples from four separate tubes taken after the prestimulatory period. B) Insulin release in per cent of total content. Washed free islet cells (about 0.5-1.0 $\times 10^{4}$ cells/tube) were first preincubated for $15 \mathrm{~min}$ in $110 \mu \mathrm{l}$ medium containing $1 \mathrm{mM}$ glucose and $10 \mathrm{mg} / \mathrm{ml}$ HSA. Following centrifugation at room temperature for 1 min at $350 \mathrm{xg}, 300 \mu \mathrm{m}$ medium was removed for insulin determination and the cell pellet was resuspended in $310 \mu \mathrm{l}$ medium supplemented with $1 \mathrm{mM}$ or $20 \mathrm{mM}$ glucose. The cells were incubated for $60 \mathrm{~min}$, centrifuged again and $300 \mu l$ medium was removed for insulin assay. The remaining volume, containing the cell pellet, was immediately frozen in melting isopentane $\left(-160^{\circ} \mathrm{C}\right)$, freeze-dried and assayed for content of insulin. C) Insulin release per $\mathrm{mm}^{3} \mathrm{PCV}$. Washed free islet cells (about $1.4 \times 10^{6}$ cells/tube) were first preincubated for $60 \mathrm{~min}$ in $5 \mathrm{ml} K R$-HEPES medium containing $3 \mathrm{mM}$ glucose and $10 \mathrm{mg} / \mathrm{ml} \mathrm{HSA}$. Following centrifugation at room temperature for 5 min at $50 \mathrm{xg}, 4.5 \mathrm{ml}$ medium was removed for insulin determination and the cell pellet was resuspended in the remaining volume. The suspension was then distributed in $50 \mu l$ volumes to microcentrifuge tubes (Fig. 6) containing $400 \mu \mathrm{l}$ medium with $3 \mathrm{mM}$ or $20 \mathrm{mM}$ glucose. The cells were incubated for $60 \mathrm{~min}$, and then centrifuged at room temperature for $5 \mathrm{~min}$ at $1000 \mathrm{xg}$. The incubation medium was removed for insulin assay and the length of the cell pellet was measured to determine the packed cell volume $(P C V)$. The $P C V$ for cells incubated at $3 \mathrm{~m} M$ glucose was $1.31 \pm 0.11 \mathrm{~mm}^{3}$ and at $20 \mathrm{mM}$ glucose $1.31 \pm 0.10 \mathrm{~mm}^{3}$ (mean values $\pm S E M$ for 12 experiments). Mean values $\pm S E M$ for the number of experiments shown within parentheses. Each experiment comprised three incubations with either glucose concentration, the mean value of which was entered as one observation in the statistical treatment. For statistical testing of the effect of glucose, t-values were computed from the mean values $\pm S E M$ of the differences between parallel incubations at 3 or $20 \mathrm{mM}$ glucose

\begin{tabular}{|c|c|c|c|}
\hline \multirow{2}{*}{$\begin{array}{l}\text { Glucose } \\
\text { concn. }\end{array}$} & \multirow{2}{*}{$\begin{array}{l}\text { Theophylline } \\
\text { concn. }\end{array}$} & \multicolumn{2}{|c|}{ Insulin release per $60 \mathrm{~min}$} \\
\hline & & $\mathrm{pg}$ insulin/cell & ng insulin/ug DNA \\
\hline $3 \mathrm{mM}$ & $0 \mathrm{mM}$ & $0.52 \pm 0.149$ & $64 \frac{1}{(8)}$ \\
\hline \multirow[t]{2}{*}{$20 \mathrm{mM}$} & $0 \mathrm{miM}$ & $0.76 \underset{(7)}{ \pm} 0.15^{*}$ & $96 \underset{(\overline{8})}{ \pm} 28 *$ \\
\hline & & \multicolumn{2}{|c|}{ Effect of $20 \mathrm{mM}$ glucose: $* \mathrm{P}<0.01$} \\
\hline
\end{tabular}

\begin{tabular}{|c|c|c|c|}
\hline $3 \mathrm{mM}$ & $5 \mathrm{mM}$ & $0.41 \frac{ \pm}{(7)} 0.15$ & $55+19$ \\
\hline \multirow[t]{3}{*}{$20 \mathrm{mM}$} & $5 \mathrm{mM}$ & $0.92 \underset{(7)}{ \pm} 0.13^{*}$ & $123 \pm 15 * *$ \\
\hline & & \multicolumn{2}{|c|}{ Fffect of $20 \mathrm{mM}$ glucose: $\begin{array}{rl}* & \mathrm{P}<0.01 \\
& * \mathrm{P}<0.005\end{array}$} \\
\hline & & $\begin{array}{l}\% \text { of total } \\
\text { insulin conte }\end{array}$ & $\mathrm{ng}$ insulin $/ \mathrm{mm}^{3} \mathrm{PCV}$ \\
\hline 1 or $3 \mathrm{mM}$ & $0 \mathrm{mM}$ & $6.54 \frac{+1.31}{(12)}$ & $260 \pm 55$ \\
\hline \multirow[t]{2}{*}{$20 \mathrm{mM}$} & $0 \mathrm{mM}$ & $9.91 \frac{1}{(12)}+89^{*}$ & $357 \underset{(12)}{ \pm}$ \\
\hline & & \multicolumn{2}{|c|}{$\begin{aligned} & \text { Effect of } 20 \mathrm{mM} \text { glucose: } * P<0.02 \\
& * * P<0.005\end{aligned}$} \\
\hline
\end{tabular}

\section{Contents of Insulin and Glucagon}

The cell contents of insulin and glucagon were determined after incubation of the cell suspensions $\left(\sim 10^{5}\right.$ cells per tube) for $120 \mathrm{~min}$ in KR-HEPES medium to $2950 \pm 102 \mathrm{ng} /$ tube and $5.6 \mathrm{ng} /$ tube respectively (mean values \pm SEM for 24 tubes from three different experiments). The insulin:glucagon ratio on a weight basis thus averaged 500:1. 


\section{Insulin Release}

The effect of glucose alone or in combination with theophylline on the release of insulin from free islet cells in suspension is summarized in Table 2. The amounts of insulin released were calculated and expressed in the following four ways: 1. pg insulin per cell, 2. ng insulin per $\mu g$ DNA, 3. insulin release in percent of total content and $4 . \mathrm{ng}$ insulin per $\mathrm{mm}^{3}$ packed cell colume (PCV). The experimental details are given in the legend to Table 2 . The appearance of the cell pellet in the capillary centrifuge tube [27] used for PCV-determination is shown in Fig. 6. As seen in Table 2, the basal insulin release obtained at low glucose concentrations ( 1 or $3 \mathrm{mM}$ ) was increased by

Table 3. Recovery of ${ }^{125} I$-insulin incubated with free islet cells. Free islet cells (about $1.0 \times 10^{5}$ cells per tube) were first preincubated for $60 \mathrm{~min}$ in $5 \mathrm{ml} K R$ - $H E P E S$ medium containing $3 \mathrm{mM}$ glucose and $10 \mathrm{mg} / \mathrm{ml} \mathrm{HSA}$. Following centrifugation at room temperature for $5 \mathrm{~min}$ at $50 \mathrm{xg}$, the cell pellet was resuspended in $2 \mathrm{ml}$ of medium supplemented with $200 \mathrm{pg}{ }^{125} \mathrm{I}$-insulin (200 $\mathrm{mCi} / \mathrm{mg}$ ) and incubated for 60 min. Samples were removed to determine total radioactivity in suspension. The cells were centrifuged and samples were taken to determine radioactivity in the supernatant. ${ }^{125} I$-insulin in each sample was precipitated in $10 \%$ (w/v) trichloroacetic acid (TCA); the precipitate was centrifuged and washed with $10 \%$ TCA before being counted in a Packard gamma spectrometer. Mean values $\pm S E M$

\begin{tabular}{lll}
\hline $\begin{array}{l}\text { Incubation } \\
\text { time }\end{array}$ & $\begin{array}{l}\text { No. of } \\
\text { exp. }\end{array}$ & $\begin{array}{l}\text { Supernatant radioactivity } \\
\text { in o of total radio- } \\
\text { activity in suspension }\end{array}$ \\
\hline 15 min & 6 & $97 \pm 0.6$ \\
$30 \mathrm{~min}$ & 6 & $96 \pm 1.0$ \\
$60 \mathrm{~min}$ & 6 & $96 \pm 0.9$ \\
\hline
\end{tabular}

roughly $50 \%$ when the glucose concentration was raised to $20 \mathrm{mM}$. This effect was slightly potentiated by $5 \mathrm{mM}$ theophylline.

Possible breakdown of insulin during the incubation procedure was studied by adding ${ }^{125} \mathrm{I}$-insulin to the cell-containing incubation medium and measuring the recovery of TCA-precipitable ${ }^{125} \mathrm{~T}$-insulin (Table 3 ). After $60 \mathrm{~min}$ of incubation $96 \%$ of the total radioactivity in the cell suspension could be recovered in the supernatant after centrifugation.

For comparison, intact, collagenase-isolated islets were incubated as described previously [16]. As is apparent from Table 4, the insulin release from these islets increased some $8-9$ fold when the glucose concentration was raised from 3 to $20 \mathrm{mM}$. This increase was markedly potentiated by theophylline.

\section{Discussion}

The technique described would seem to offer certain advantages in studies on the endocrine pancreas. Without extensive manipulation, free islet cells in fairly good yields can be isolated within a reasonable period of time. The free cells obtained seemed to ex- hibit a high degree of viability as judged by viable cell counts, a radioactive assay for cell lysis, and their insulin-releasing capacity. The cells in general appeared to be well preserved in both the light and the electron microscope. It may be added that a separate experiment showed that the isolated cells could be maintained in a monolayer culture (Eagle minimal essential medium containing $20 \%(\mathrm{v} / \mathrm{v})$ calf serum) for at least $7-8$ days. These findings indicate that disruption of the pancreatic islets does not seriously affect individual, isolated islet cells.

Islet cells have previously been isolated by, for example, gentle squashing [24] or by enzymatic treatment of the islets with collagenase and hyaluronidase

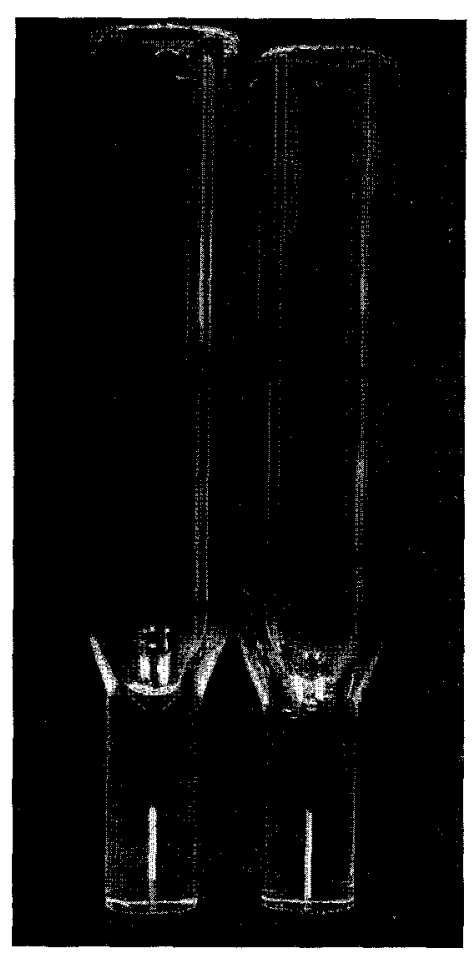

Fig. 6. Pellets of free islet cells in the capillary centrifuge tube used for packed cell volume determinations. The upper part of the Trubore precision glass (Ace Glass Inc., Vineland, N.J.) tube is $35 \mathrm{~mm}$ long with an internal diameter of $5 \mathrm{~mm}$. The lower part is $10 \mathrm{~mm}$ long, the internal diameter being $0.508 \pm 0.0013 \mathrm{~mm}$. The conical connection between the two parts is $5 \mathrm{~mm}$ long

[9] or trypsin [26]. Such methods have yielded limited. numbers of cells, although sufficient for histochemical $[24,17]$ or interferometric studies $[25,26]$. Free islet cells were recently prepared by Krause et al. [13] from isolated rat islets first incubated in a $\mathrm{Ca}^{2+}, \mathrm{Mg}^{2+}$-free medium and then disintegrated by aspiration through a syringe-needle. The release of insulin from the resulting suspension of islet cells was stimulated with sulfonylureas but not with glucose.

In the present study, islets were isolated from the pancreas of the obese-hyperglycemic mouse. This ma- 
terial is advantageous, as these pancreata not only contain considerable numbers of enlarged islets, but the latter also consist mainly of insulin-producing $\beta$ cells [8]. In the islet cell suspensions, glucagon-producing $\alpha_{2}$-cells constituted only a minor fraction. This was established both histologically and by direct measurements of glucagon in extracts from isolated cells. These results, together with published data on $\alpha_{2}$-cell dry weight [24] and glucagon content [20], seem to indicate that roughly $3 \%$ of the isolated cells were of the $\alpha_{2}$ type.

Isolated cell preparations in general are advantageous in that experimental findings can be expressed on a "per cell" basis. However, accurate determination
It has been suggested that secretion from intact islets may depend on the integrity of couplings between the individual $\beta$-cells [23]. The disruption of such couplings could perhaps in part explain why the free islet cells seemed to exhibit a reduced secretory response to glucose, although this reduction is largely accounted for by an increase of the apparent secretory rate at low glucose concentrations. Studies are in progress to help answer the question whether there was a truly enhanced basal secretion from all free cells or merely a contamination of the cell suspension with insulin from a few, seriously damaged $\beta$-cells. It should be emphasized that in all the experiments reported here, glucose exerted a clear-cut stimulation of insulin

Table 4. Effect of glucose and theophylline on insulin release from collagenase-isolated mouse islets. Islets were first preincubated for 40 min in $H E P E S$ buffered Krebs-Ringer medium containing $3 \mathrm{mM}$ glucose and $1 \mathrm{mg} / \mathrm{ml}$ BSA. They were then incubated for $60 \mathrm{~min}$ in $300 \mathrm{\mu l}$ medium supplemented as indicated. The amounts of insulin released are expressed as $n g / \mu g$ dry islet per $h$. Mean values $\pm S E M$ for the number of experiments indicated within parentheses. Statistical significances were estimated from the mean differences between parallel test and control incubations with islets from the same animals

\begin{tabular}{|c|c|c|c|}
\hline $\begin{array}{l}\text { Glucose } \\
\text { conca. }\end{array}$ & $\begin{array}{l}\text { Theophylline } \\
\text { conen. }\end{array}$ & Insulin release & $\begin{array}{l}\text { (ng/ug dry islet per hr) } \\
\text { p-value for effect } \\
\text { of glucose }\end{array}$ \\
\hline
\end{tabular}

\begin{tabular}{llcl}
\hline $3 \mathrm{mM}$ & 0 & $0.30 \pm 0.07$ & \\
$20 \mathrm{mM}$ & 0 & $2.63 \pm 1.01$ & $<0.05$ \\
$3 \mathrm{mM}$ & $5 \mathrm{mM}$ & $0.66 \pm 0.20$ & \\
$20 \mathrm{mM}$ & $5 \mathrm{mM}$ & $14.71 \pm 3.27$ & $<0.001$ \\
\hline
\end{tabular}

of cell numbers is an important factor in any such system. In the present study, therefore, the time-consuming, and only limitedly accurate, direct cell counts were complemented by DNA determination. A simple alternative to these procedures is the determination of packed cell volumes, which may well suffice for certain types of experiments.

The values for total DNA content per $\mu \mathrm{g}$ islet dry weight in the mice employed are in agreement with those reported for normal mouse [4] and rat pancreatic islets [3, 28]. The amount of DNA found per free islet cell was $5.21 \mathrm{pg}$. The DNA content of rat pancreatic cells has previously been estimated to $7-10 \mathrm{pg} / \mathrm{cell}$ $[29,18]$. From the values of DNA content per $\mu \mathrm{g}$ dry islet and per islet cell, the number of cells per $\mu \mathrm{g}$ islet dry weight can be calculated to 3600 . Disregarding islet elements other than the endocrine cells, the dry weight of each islet cell would be of the order of $280 \mathrm{pg}$. In interferometric studies of single islet cells, Petersson [25] found that the $\beta$-cell dry mass in obese-hyperglycemic mice amounted to $180 \mathrm{pg}$. Applying this figure, it can be calculated that DNA comprises roughly $2.8 \%$ of the $\beta$-cell dry mass and that the $\beta$-cells in the islets of Langerhans thus contribute $65 \%$ of the islet dry weight. release, indicating that the free islet cells may be useful in further studies on the insulin-releasing mechanisms.

This work was supported by the Swedish Medical Research Council (project $12 \mathrm{X}-3923$ ). The author is indebted to Professor Gunnar D. Bloom for aid with the electron microscopy and to Miss Gerd Larsson and Miss Marianne Borg for skilful technical assistance.

\section{References}

1. Clark, W.R.: The synthesis and accumulation of insulin in the rat embryo during development. In: Ph. D. Thesis, University of Washington (1968)

2. DeRenzis, R. A., Schechtman, A.: Staining by neutral red and trypan blue in sequence for assaying vital and nonvital cultured cells. Stain Technol. 48, 135-136 (1973)

3. Green, I.C., Taylor, K.W.: Effects of pregnancy in the rat on the size and insulin secretory response of the islets of Langerhans. J. Endocr. 54, 317-325 (1972)

4. Hedeskov, C.J., Hertz, L., Nissen, C.: The effect of mannoheptulose on glucose- and pyruvate-stimulated oxygen uptake in normal mouse pancreatic islets. Biochim. biophys. Acta 261, 388-397 (1972)

5. Heding, L.G.: A simplified insulin radioimmunoassay method. In: Labelled Proteins in Tracer Studies. Donato, L., Milhaud, G., Sirchis, G., Eds.) Brussels: Euratom 345-350 1966 
6. Heding, L. G.: Radioimmunological determination of pancreatic gut glucagon in plasma. Diabetologia 7 , $10-19(1970)$

7. Hellerström, C. : A method for microdissection of in. tact pancreatic islets of mammals. Acta endocr. (Kbh.) 45, $122-132(1964)$

8. Hellman, B.: Studies in obese-hyperglycemic mice. Ann. N.Y. Acad. Sci. 131, 541-558 (1965)

9. Hellman, B., Lernmark, $\AA$. : Methods for the isolation of cells with special reference to the pancreatic islets. In: Recent Advances in Quantitative Histo- and Cytochemistry. (Dubach, U.C., Schmidt, U., Eds.) Bern: Verlag: Hans Huber 91-108 (1971)

10. Hellman, B., Täljedal, I.B.: Histochemistry of the pancreatic islet cells. In: Handbook of Physiology. Section 7 : Endocrinology, Vol. I. Endocrine pancreas. (Steiner, D.F., and Freinkel, N., Eds.) Baltimore: Williams and Wilkins Company $91-110(1972)$

11. Keen, H., Sells, R., Jarrett, R.J.: A method for the study of the metabolism of isolated mammalian islets of Langerhans and some preliminary studies. Diabetologia 1, 28-32 (1965)

12. Kissane, J.M., Robins, E.: The fluorometric measurement of deoxyribonucleic acid in animal tissues with special reference to the central nervous system. J. biol. Chem. 233, 184-188 (1958)

13. Krause, U., Puchinger, H., Wacker, A.: Inhibition of glucose-induced insulin secretion in trypsin-treated islets of Langerhans Horm. Metab. Res. 5, 325-329 (1973)

14. Lacy, P., Greider, M.H.: Ultrastructural organization of mammalian pancreatic islets. In: Handbook of Physiology, Section 7: Endocrinology, Vol. I. Endocrine pancreas. Steiner, D.F., and Freinkel, N., editors. Baltimore: The Williams and Wilkins Company, $77-89(1972)$

15. Lacy, P., Kostianovsky, M. : Method for the isolation of intact islets of Langerhans from the rat pancreas. Diabetes 16, 35-39 (1967)

16. Lernmark, $\AA$.: Isolated mouse islets as a model for studying insulin release. Acta Diabet. Lat. 8, 649679 (1971a)

17. Lernmark, $\AA$.: The significance of 5-hydroxytryptamine for insulin secretion in the mouse. Horm. Metab. Res. 3, 305--309 (1971 b)

18. Leslie, I. : The nucleic acid content of tissues and cells. In: The Nucleic Acids, Vol. II. (Chargaff, E., and Davidson, J.N., Eds.) New York: Academic Press (1955)

19. Luft, J.H.: Improvements in epoxy resin embedding methods. J. Biophys. Biochem. Cytol. 9, 409-414 (1961)
20. Lundquist, G., Brolin, S. E., Unger, R.H., Eisentraut, A.M.: The cellular origin of pancreatic glucagon. In: The Structure and Metabolism of the Pancreatic Islets. (Falkmer, S., Hellman, B. and Täljedal, I.B., Eds.) Oxford: Pergamon Press 115-121 (1970)

21. Merchant, D.J., Kahn, R.H., Murphy, Jr.,W.H.: Handbook of cell and organ culture. Minneapolis: Burgess Publishing Company 1967

22. Moskalewsky, S.: Isolation and culture of the islets of Langerhans of the guinea-pig. Gen. comp. Endocr. 5, $342-353(1965)$

23. Orci, L., Unger, R.H., Renold, A.E. : Structural coupling between pancreatic islet cells. Experientia 29, $1015-1018$ (1973)

24. Peterson, B.: Isolation and characterization of different types of pancreatic islet cells in guinea-pigs. Acta Endocr. (Kbh.) 53, 480-488 (1966)

25. Petersson, B.: The dry mass of the pancreatic $\beta$-cells in relation to their content of secretion granules. Histochem. J. 1, 55-58 (1968)

26. Petersson, B., Gunnarsson, R., Hellerström, C., Andersson, A.: A method for enzymatic dissociation of cells from isolated pancreatic islets. Acta Diabet. Lat. 10, $725-736$ (1973)

27. Saladino, A.J., Waybrant, R.C.: A simple procedure for collection of small quantities of cells from suspensions for microanalytical studies. Exp. Cell Res. 63, $467-470(1971)$

28. Steinke, J., Patel, T.N., Ammon, H.P.T.: Relationship between glucose- and tolbutamide-induced insulin release and insulin content in single pancreatic rat islets. Metabolism 21, $465-470$ (1972)

29. Thomson, R.Y., Heagy, F.C., Hutchison, W.C., Davidson, J.N.: The deoxyribonucleic acid content of the rat cell nucleus and its use in expressing the results of tissue analysis, with particular reference to the composition of liver tissue. Biochem. J. 53, 460474 (1953)

30. Umbreit, W.W., Burris, R.H., Stauffer, J.F.: Manometric tochniques. Burgess Publishing Co., Minneapolis (1964)

31. Wigzell, H.: Quantitative titrations of mouse H-2 antibodies using ${ }^{51} \mathrm{Cr}$-labelled target cells. Transplantation, 3, 423-431 (1965)

Dr. A. Lernmark

Dept. of Histology

Univ. of Umeå

S-90/87 Umeå

Sweden 